\title{
Pollen morphology of Philippine species of Phyllanthus (Phyllanthaceae, Euphorbiaceae s.I.)
}

\author{
Y.-J. Chen ${ }^{1}$, S.-H. Chen ${ }^{1}$, T.-C. Huang ${ }^{2}$, M.-J. Wu ${ }^{1}$
}

Key words

Euphorbiaceae

Philippines

Phyllanthaceae

Phyllanthus

pollen morphology

SEM

taxonomy

\begin{abstract}
The pollen morphology of 21 Philippine Phyllanthus species belonging to five subgenera and eleven sections was studied using scanning electron microscopy. Eleven pollen types were recognized, of which seven were previously reported and four are newly described, i.e., the Phyllanthus erythrotrichus type, the $P$. glochidioides type, the $P$. securinegoides type and the Pilate type. The pollen morphology of the Philippine Phyllanthus species included in this study provides insight into the taxonomy as well as the phylogeny of these species.
\end{abstract}

Published on 30 October 2009

\section{INTRODUCTION}

Phyllanthus is the largest genus of the Phyllanthaceae (Euphorbiaceae s.l.). It contains about 830 species (Govaert et al. 2000). On the basis of a large molecular analysis of Phyllanthus and its relatives, Kathriarachchi et al. (2006) recommended the inclusion of Breynia, Glochidion, Reverchonia and Sauropus to form a large monophyletic genus Phyllanthus s.l. This genus would then comprise c. 1269 species (Govaert et al. 2000). They found that the subgenera Conami, Emblica, Eriococcus, Gomphidium (sensu Schmid 1991) and Xylophylla (except for $P$. sellowianus) are monophyletic, whereas the subgenera Isocladus, Kirganelia and Phyllanthus appeared to be not monophyletic. Most clades obtained in their analyses were supported by palynological characters.

In the study of the West Indian species of Phyllanthus, Webster (1956) discovered the extraordinary diversity of pollen morphology within the species using light microscope (LM). Punt (1967) showed two series of Phyllanthus pollen types and proposed their evolutionary trends. The precise usage of pollen characters in taxonomy for the small pollen size, usually around $20-30 \mu \mathrm{m}$ diam is difficult, therefore the aid of scanning electronic microscope (SEM) in the observation of the exine ornamentation is necessary. At least 30 pollen types were reported in 220 species of Phyllanthus studied using LM and/or SEM (Erdtman 1952, Webster 1956, 1986, Köhler 1965, 1967, Punt 1967, 1972, 1980, 1987, Punt \& Rentrop 1973, Bor 1979, Meewis \& Punt 1983, Long \& Yu 1984, Rossignol et al. 1987, Lobreau-Callen et al. 1988, Chen \& Wu 1997, Webster \& Carpenter 2002, Wei et al. 2002, Sagun \& Van der Ham 2003, Santiago et al. 2004).

In the Philippines, more than 30 species of Phyllanthus have been reported previously and can be classified into five subgenera and eleven sections (Elmer 1908, 1910, 1911, Robinson 1909, 1911, Merrill 1912, 1914, 1920, 1923, Quisumbing \& Merrill 1928, Airy Shaw 1983, Hoffmann et al. 2003). The

\footnotetext{
Graduate Institute of Biological Resources and Technology, National Dong Hwa University, Meilun Campus, formerly known as National Hualien University of Education, Hualien 970, Taiwan.

2 Institute of Plant Biology, National Taiwan University, Taipei 106, Taiwan.
}

minute unisexual flowers and the variable leaf morphology caused the classification of some species to remain in doubt. In order to provide new evidence for the species classification, we undertook the present pollen morphological study of Philippine Phyllanthus species.

\section{MATERIAL AND METHODS}

Pollen samples were collected from specimens deposited in the following herbaria: L, NHU, PUH (Table 1).

Per sample, anthers of $1-3$ flowers were placed in $1.5 \mathrm{ml}$ centrifuge tubes, immersed in acetic acid for 30 min until soft, crushed by a glass bar to release the pollen grains, and then acetolyzed (Erdtman 1952). The acetolyzed pollen was then dehydrated in a series of $70 \%, 90 \%$ and $100 \%$ ethanol and pipeted onto a filter membrane to be air dried. Under a thin layer of gold coating, the pollen grains were examined and photographed using a Hitachi S-800 Scanning Electron Microscope. Pollen size was based on measuring 2-4 pollen grains per sample. The terminology used in this paper follows Huang (1972) and Punt et al. (2007).

\section{RESULTS}

Eleven pollen types were recognized in the Philippine Phyllanthus species studied (Table 2), seven of which have been reported previously and four $(P$. erythrotrichus type, $P$. glochidioides type, $P$. securinegoides type, Pilate type) might be reported here for the first time. A key to the pollen types is presented below.

\section{Key to the pollen types}

1. Pollen grain pantoporate ........... P. buxifolius type

1. Pollen grain colporate, syncolporate or areolate (i.e. pantosyncolpate). . . . . . . . . . . . . . . 2

2. Pollen grain syncolporate or areolate (i.e. pantosyncol-

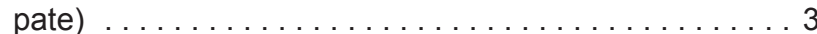

2. Pollen grain colporate .............. 5

3. Pollen grain areolate (i.e. pantosyncolpate), with 16-26 colpi . . . . . . . . . . . . . . . . Pirgatus type

3. Pollen grain syncolporate, with three colpi $\ldots \ldots \ldots \ldots 4$

(c) 2009 Nationaal Herbarium Nederland

You are free to share - to copy, distribute and transmit the work, under the following conditions:

Attribution: $\quad$ You must attribute the work in the manner specified by the author or licensor (but not in any way that suggests that they endorse you or your use of the work). 
4. Lumina of the reticulum with granules .. P. maritimus type

4. Lumina of the reticulum without granules $P$. casticum type

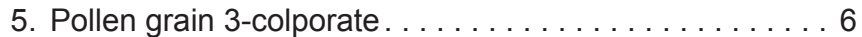

5. Pollen grain 4- or 5-colporate . . . . . . . . . 8

6. Colpi nearly confluent at the poles, exine ornamentation rugulate-reticulate .............. acidus type

6. Colpi not confluent at the poles, exine ornamentation bireticulate or striate-reticulate $\ldots \ldots \ldots \ldots \ldots \ldots$

7. Exine ornamentation bi-reticulate, pollen grain subprolate to prolate . . . . . . . . . . . . . P. amarus type

7. Exine ornamentation striate-reticulate, pollen grain prolate $P$. erythrotrichus type
8. Exine ornamentation pilate, colpi obscure.... Pilate type

8. Exine ornamentation reticulate or bi-reticulate, colpi distinct $\ldots \ldots \ldots \ldots \ldots \ldots \ldots \ldots \ldots \ldots \ldots \ldots \ldots \ldots \ldots \ldots$

9. Exine ornamentation bi-reticulate, pollen grain 4- or 5-colporate ................. P. urinaria type

9. Exine ornamentation reticulate, pollen grain 4-colporate.

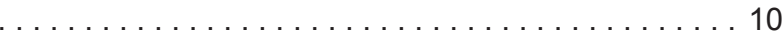

10. Colpus margins smooth, muri round verrucate $\ldots \ldots \ldots \ldots \ldots \ldots \ldots$. securinegoides type

10. Colpus margins ragged, muri coniculate

P. glochidioides type

Table1 Locality and voucher specimens of the Philippine Phyllanthus species sampled in this study.

\begin{tabular}{|c|c|c|}
\hline Species & Location & Voucher \\
\hline P. acidus (L.) Skeels & Santa, Luzon & Gaerlan, F.J.M. et al. PPI 10249 (L) \\
\hline P. amarus Schumach. \& Thonn. & Palawan & Wu, M.-J. 2951 (NHU) \\
\hline P. benguetensis C.B.Rob. & Luzon & Merrill, E.D. 9684 (L) \\
\hline P. buxifolius (Blume) Müll.Arg. & Bohol & Ramos, M. BS 43248 (L) \\
\hline P. erythrotrichus C.B.Rob. & Susong-Dalaga, Luzon & Robinson, C.B. BS 29333 (L) \\
\hline P. glochidioides Elmer & Paraiso, Luzon & Edaño, G.E. PNH 40177 (L) \\
\hline P. kinabaluicus Airy Shaw & Beaufort Mountain, Palawan & Ridsdale, C.E. SMHI 241 (L) \\
\hline$P$. lanceifolius Merr. & Catanduanes & Ramos, M. \& G. Edano BS 75281 (PUH) \\
\hline P. megalanthus C.B.Rob. & Luzon & Curran, H.M. FB 17243 (L) \\
\hline P. mindorensis C.B.Rob. & Lobo, Luzon & Sulit, M.D. PNH 15718 (L) \\
\hline P. ramosii Quisumb. \& Merr. & Luzon & Mabesa, C. $853(L)$ \\
\hline P. reticulatus Poir. & Los Baños, Luzon & Hallier, J.G. 4117 (L) \\
\hline$P$. samarensis Müll.Arg. & Paranas, Samar & Reynoso, E.J. PPI 7550 (L) \\
\hline P. securinegoides Merr. & Panacan, Palawan & Sulit, M.D. PNH 16268 (L) \\
\hline P. sibuyanensis Elmer & Magallanes, Sibuyan & Elmer, A.D.E. $12113(\mathrm{~L})$ \\
\hline P. virgatus G.Forst. & Palawan & Wu, M.-J. 2953 (NHU) \\
\hline P. aff. glochidioides & Tagkawayan, Luzon & Lagrimas, M.Q. PNH 39954 (L) \\
\hline$P$. aff. samarensis & Santa Cruz, Luzon & Ridsdale, C.E.1479 (L) \\
\hline Phyllanthus sp. A & Bohol & Ramos, M. BS 43203 (L) \\
\hline
\end{tabular}
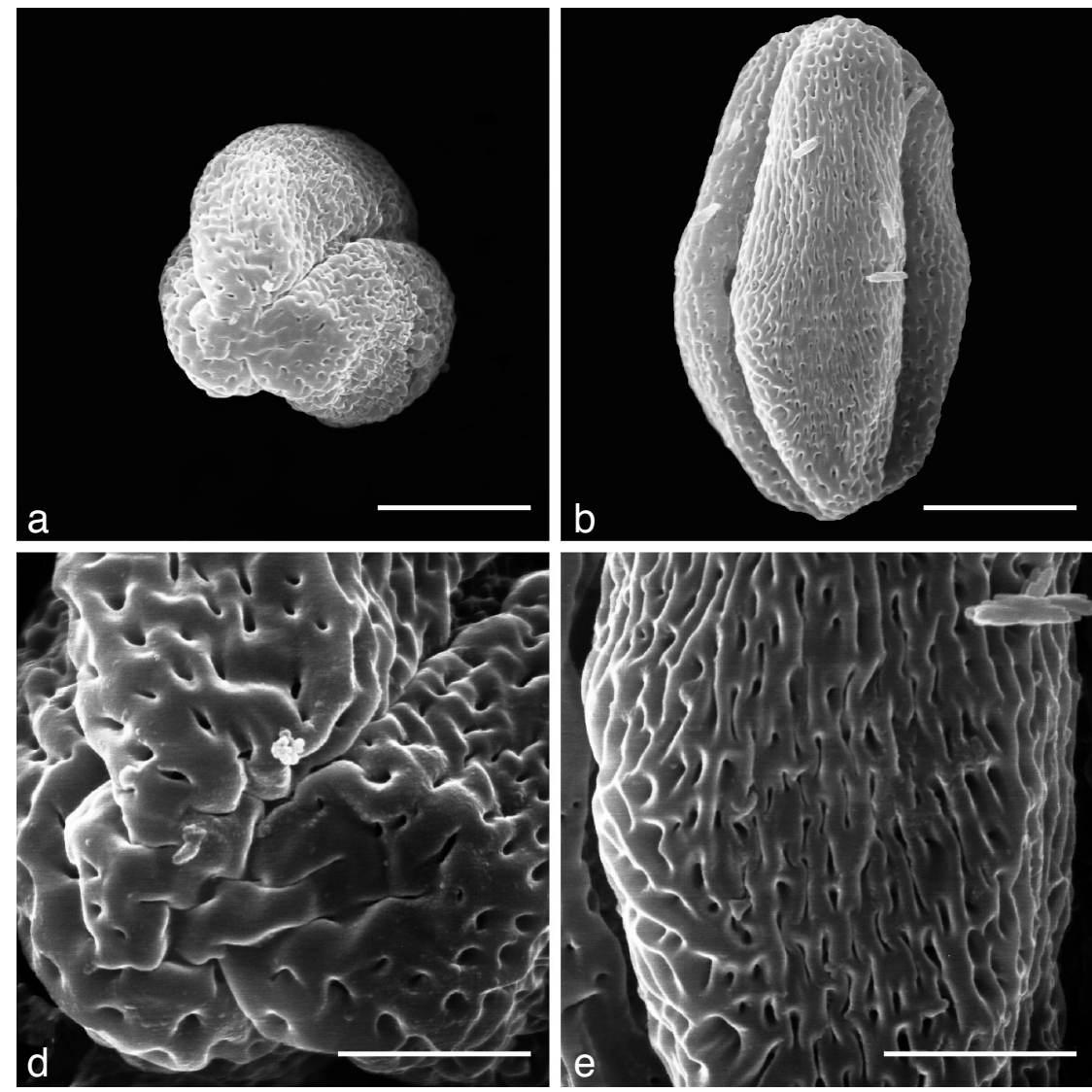
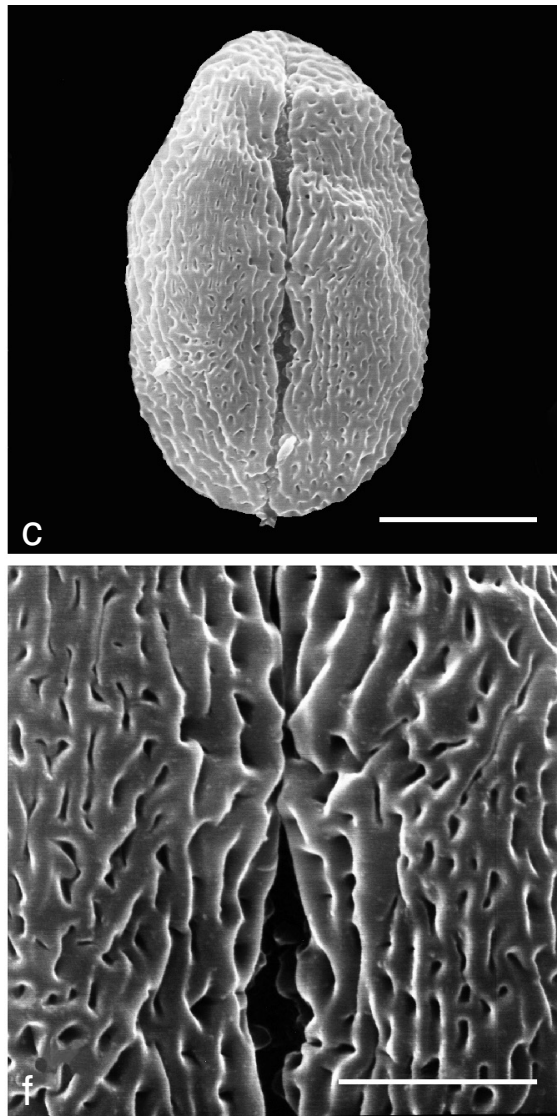

Fig. 1 Scanning electron micrographs of the Phyllanthus erythrotrichus type. a-f. P. erythrotrichus. - Scale bars: $a-c=5 \mu \mathrm{m}, d-f=2 \mu \mathrm{m}$. 

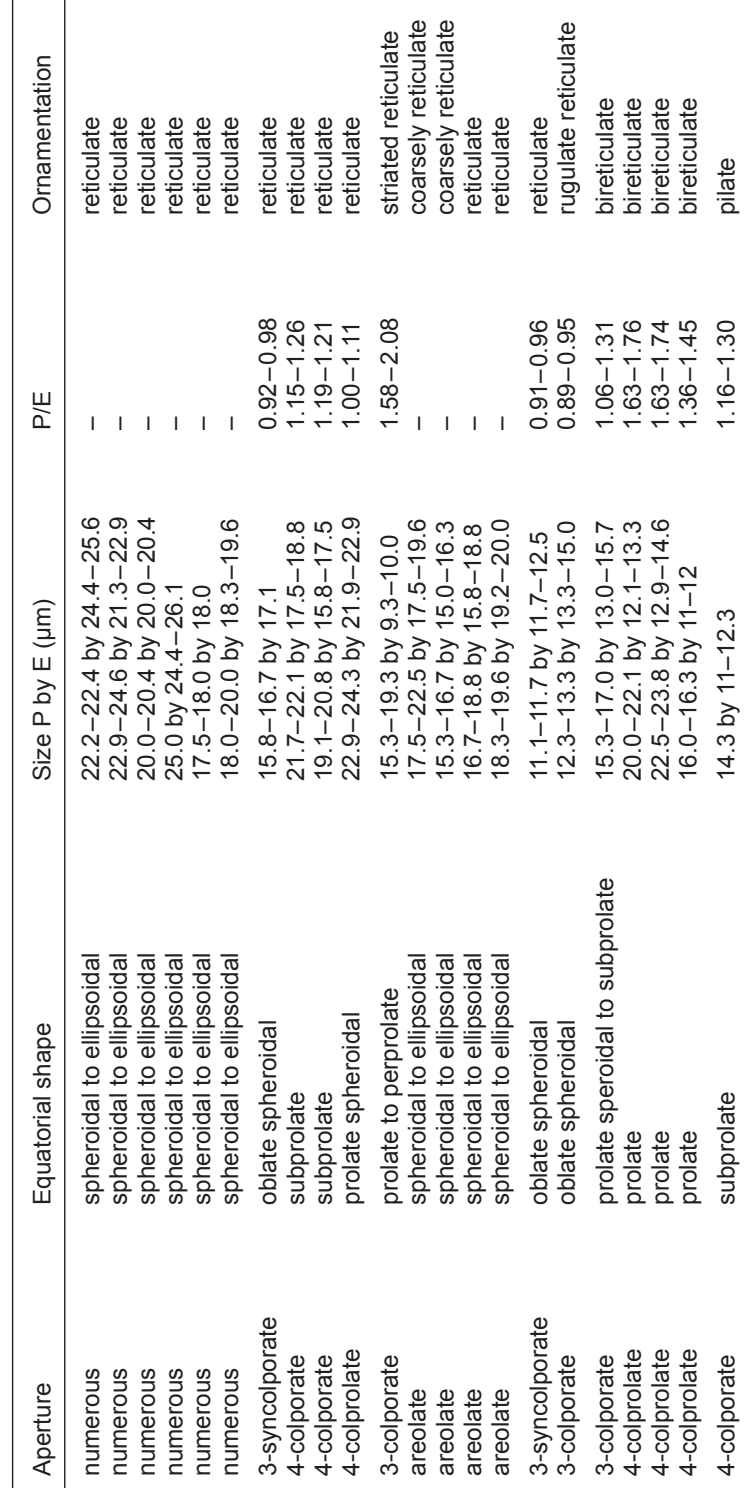

(1)
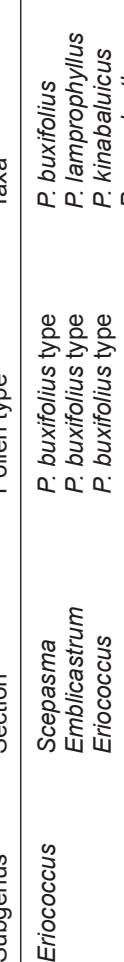
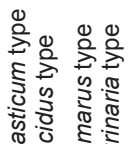
Q. Q Q Q Q Q

\section{DESCRIPTION OF THE POLLEN TYPES}

\section{Phyllanthus erythrotrichus type - Fig. 1}

Pollen grains prolate to perprolate. $\mathrm{P}=15.3-19.3 \mu \mathrm{m}, \mathrm{E}=$ 9.3-10.0 $\mu \mathrm{m}, \mathrm{P} / \mathrm{E}=1.58-2.08$.

Aperture system - 3-colporate.

Ornamentation - Striate-reticulate, lumina small and narrow.

Species included $-P$. erythrotrichus.

Note - The ornamentation is similar to that of the $P$. urinaria type, but the lumina are narrower.

\section{Phyllanthus virgatus type - Fig. 2, 3}

Pollen grains spheroidal to ellipsoidal. Polarity unknown. Size $=15.3-22.5$ by $15.0-20.0 \mu \mathrm{m}$.

Aperture system - Areolate (i.e. pantosyncolpate).

Ornamentation - Reticulate to coarsely reticulate.

Species included - $P$. lanceifolius, $P$. samarensis, $P$. virgatus, $P$. aff. samarensis.

Note - The number of lumina per areola varies: $P$. lanceifolius and $P$. samarensis: $\pm 30, P$. virgatus: \pm 60 , and Phyllanthus aff. samarensis: \pm 70 . Phyllanthus aff. samarensis differs from the other species of the $P$. virgatus type by its colpus margins consisting of two parallel muri rather than four.

References - Punt 1980, 1987, Long \& Yu 1984, Webster 1986, Lobreau-Callen et al.1988, Chen \& Wu 1997.

\section{Phyllanthus casticum type - Fig. 4}

Pollen grains oblate spheroidal. $\mathrm{P}=11.1-11.7 \mu \mathrm{m}, \mathrm{E}=11.7-$ $12.5 \mu \mathrm{m}, \mathrm{P} / \mathrm{E}=0.91-0.96$.

Aperture system - 3-syncolporate.

Ornamentation - Reticulate.

Species included $-P$. reticulatus.

Note - This type is similar to the $P$. acidus type, but differs by its confluent colpi.

References - Köhler 1965, Punt 1967, 1980, Bor 1979, Long \& Yu 1984, Lobreau-Callen et al. 1988.

\section{Phyllanthus acidus type - Fig. 5}

Pollen grains oblate spheroidal. $\mathrm{P}=12.3-13.3 \mu \mathrm{m}, \mathrm{E}=13.3-$ $15.0 \mu \mathrm{m}, \mathrm{P} / \mathrm{E}=0.89-0.95$.

Aperture system - 3-colporate, colpi nearly confluent at the poles.

Ornamentation - Rugulate-reticulate.

Species included $-P$. acidus.

References - Köhler 1965, 1967, Punt 1967.

\section{Phyllanthus amarus type}

Pollen grains prolate spheroidal to subprolate. $\mathrm{P}=15.3-17.0$ $\mu \mathrm{m}, \mathrm{E}=13.0-15.7 \mu \mathrm{m}, \mathrm{P} / \mathrm{E}=1.06-1.31$.

Aperture system - 3-colporate.

Ornamentation - Bi-reticulate.

Species included $-P$. amarus.

Note - This type and the $P$. urinaria type have both bireticulate ornamentation, but they differ in the number of colpi.

References - Punt \& Rentrop 1973, Bor 1979, Punt 1980, Long \& Yu 1984, Chen \& Wu 1997. 

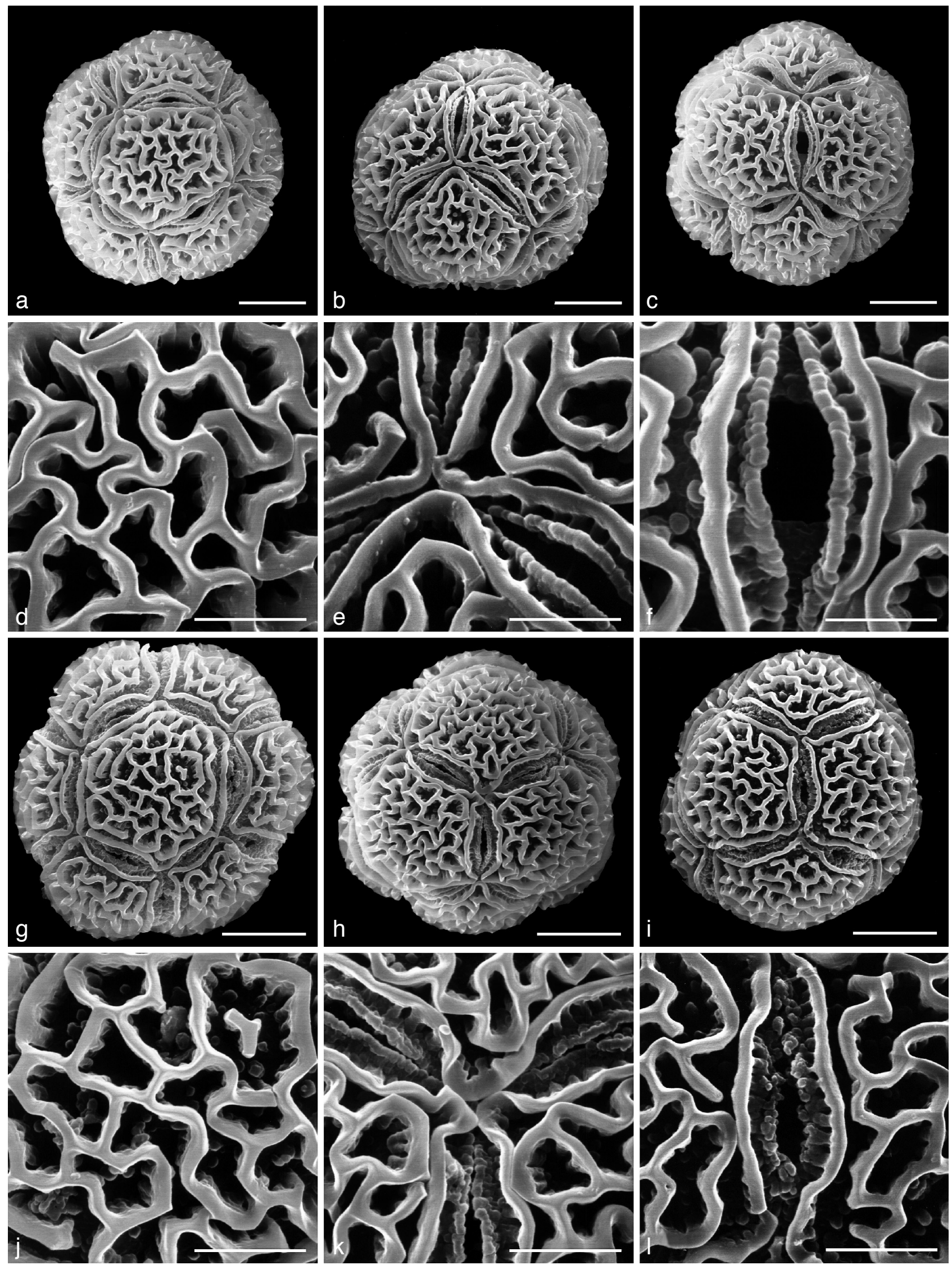

Fig. 2 Scanning electron micrographs of the Phyllanthus virgatus type. a-f. P. lanceifolius; $g-I$. P. samarensis. - Scale bars: $a-c, g-i=5 \mu m, d-f, j-I=$ 

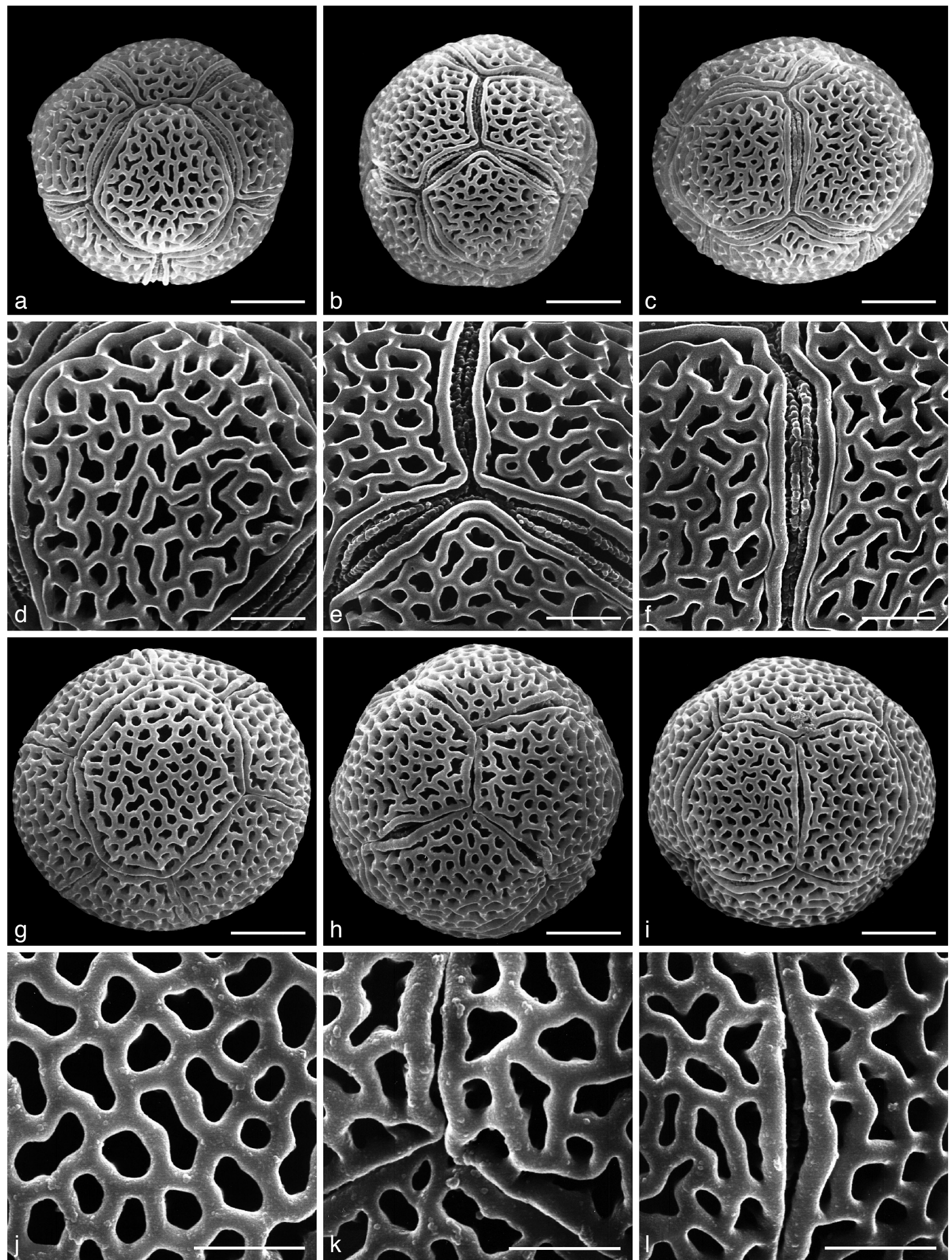

Fig. 3 Scanning electron micrographs of the Phyllanthus virgatus type. a-f. P. virgatus; $\mathrm{g}-\mathrm{I}$. $P$. aff. samarensis. - Scale bars: $\mathrm{a}-\mathrm{c}, \mathrm{g}-\mathrm{i}=5 \mu \mathrm{m} ; \mathrm{d}-\mathrm{f}, \mathrm{j}-\mathrm{I}=$ $2 \mu \mathrm{m}$. 


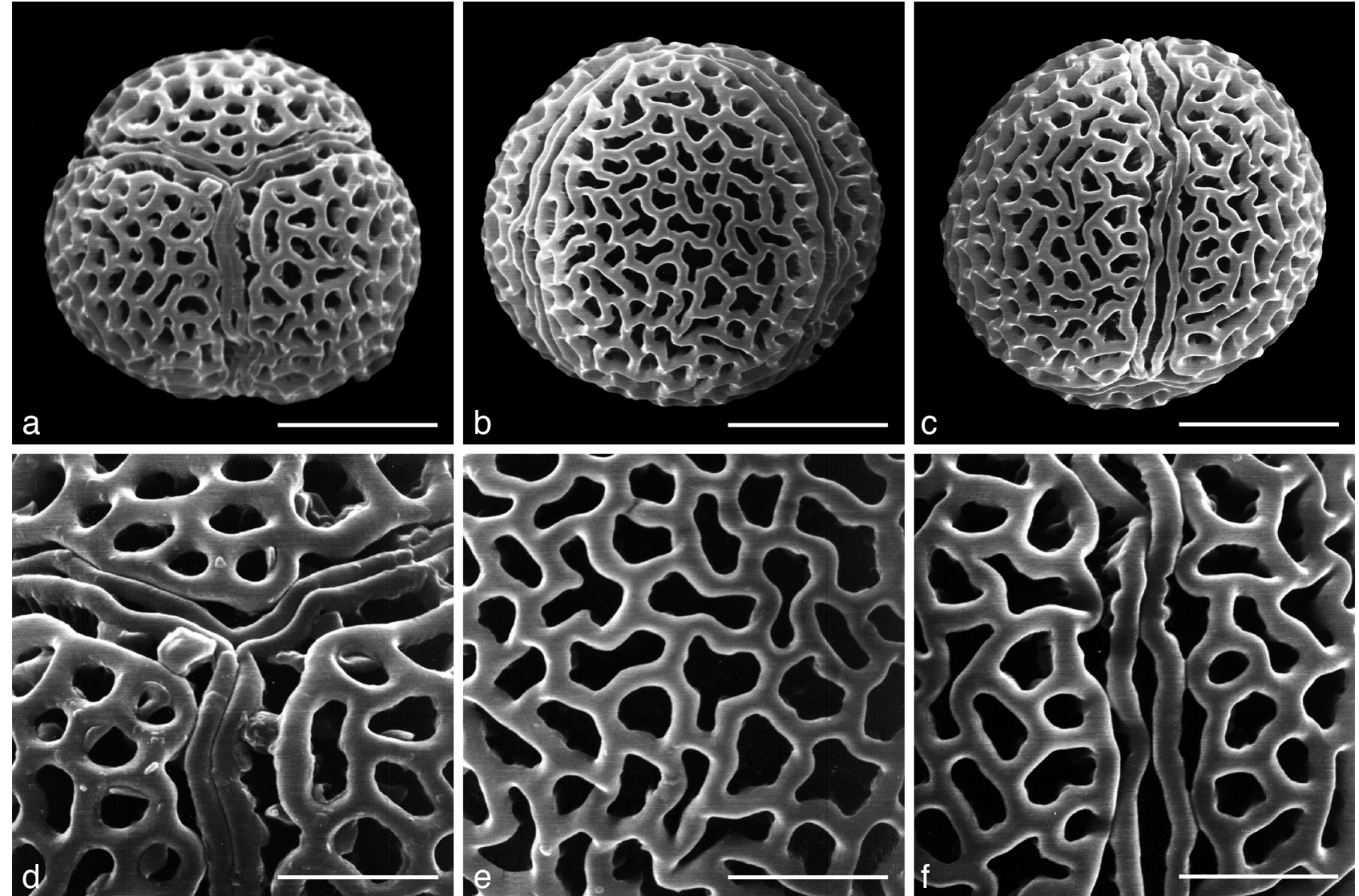

Fig. 4 Scanning electron micrographs of the Phyllanthus casticum type. a-f. P. reticulatus. - Scale bars: $a-c=5 \mu m, d-f=2 \mu \mathrm{m}$.
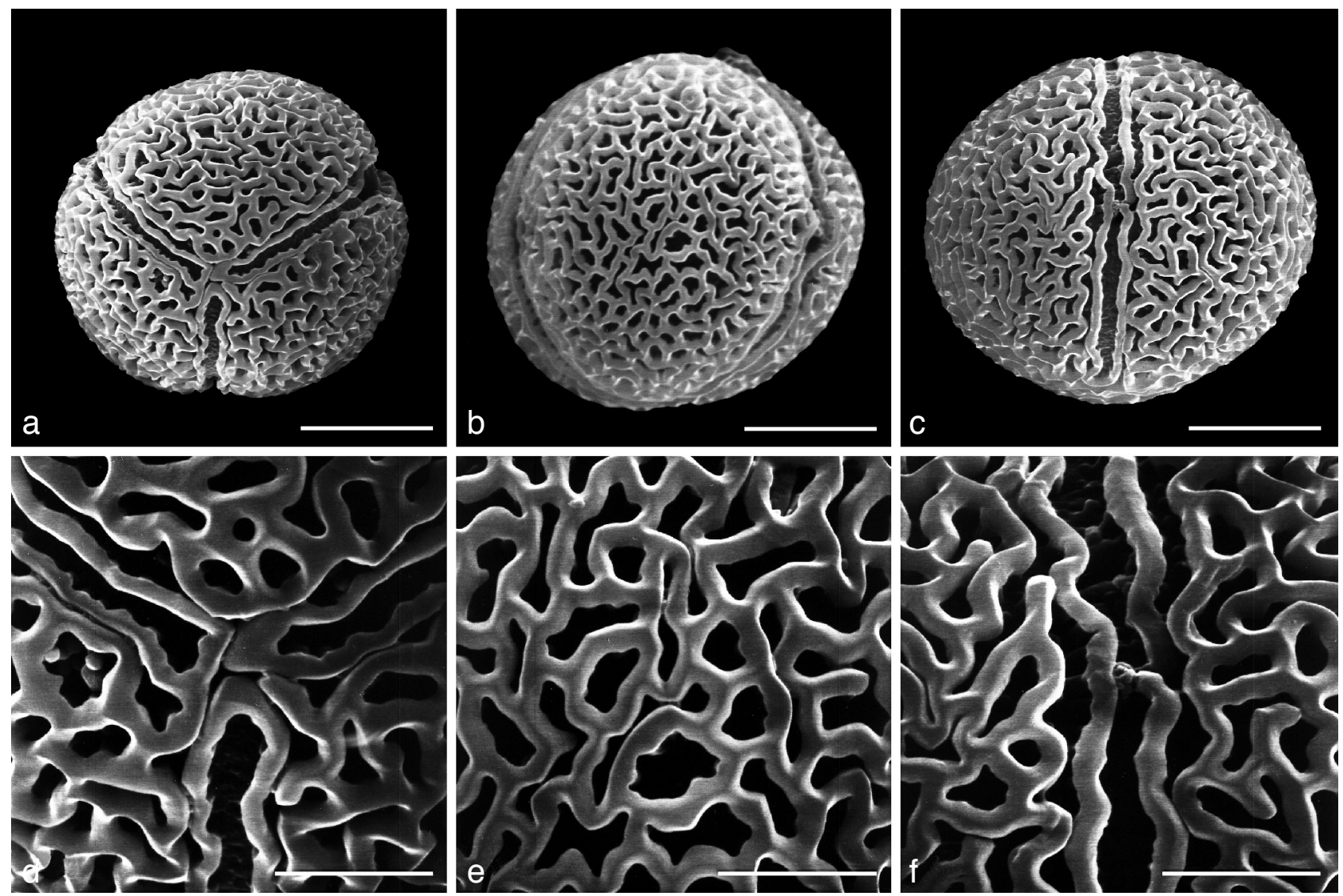

Fig. 5 Scanning electron micrographs of the Phyllanthus acidus type. a-f. P. acidus. - Scale bars: $a-c=5 \mu \mathrm{m}, d-f=2 \mu \mathrm{m}$. 


\section{Phyllanthus urinaria type - Fig. 6}

Pollen grains prolate. $P=16.0-23.8 \mu \mathrm{m}, E=11.05-14.6 \mu \mathrm{m}$, $\mathrm{P} / \mathrm{E}=1.36-1.76$.

Aperture system - 4- or 5-colporate, colpi narrow.

Ornamentation - Bi-reticulate.

Species included $-P$. benguetensis, $P$. urinaria (both subspecies).

Note - Rossignol et al. (1987) found that species in sect. Urinaria with chromosome number $2 n=50$ have 4 -colporate pollen, while species with chromosome number $2 n=100$ have 5-colporate pollen.

References - Punt \& Rentrop 1973, Bor 1979, Long \& Yu 1984, Rossignol et al. 1987, Chen \& Wu 1997.

\section{Phyllanthus buxifolius type - Fig. 7}

Pollen grains spheroidal to ellipsoidal. Polarity unknown. Size $=17.5-25.3$ by $18.0-26.1 \mu \mathrm{m}$.

Aperture system - Pantoporate.

Ornamentation - Coarsely reticulate, less than 10 granules per lumen.

Species included $-P$. buxifolius, $P$. kinabaluicus, $P$. lamprophyllus, $P$. megalanthus, $P$. mindorensis, $P$. sibuyanensis.

References - Punt 1980, 1987, Long \& Yu 1984, Wei et al. 2002.

\section{Phyllanthus maritimus type - Fig. 8}

Pollen grains oblate spheroidal. $P=15.8-16.7 \mu \mathrm{m}, E=17.1 \mu \mathrm{m}$, $\mathrm{P} / \mathrm{E}=0.92-0.98$.

Aperture system - 3-syncolporate.

Ornamentation - Reticulate, lumina with small granules.

Species included $-P$. ramosii.
Note - The P. maritimus type is similar to the $P$. casticum type, but differs by the presence of granules in the lumina.

References - Punt 1980, Meewis \& Punt 1983.

\section{Phyllanthus glochidioides type - Fig. 9}

Pollen grains subprolate. $P=17.1-22.1 \mu \mathrm{m}, E=15.8-18.8 \mu \mathrm{m}$, $\mathrm{P} / \mathrm{E}=1.15-1.26$.

Aperture system - 4-colporate, colpi slit-like, with ragged margins.

Ornamentation - Coarsely reticulate.

Species included - P. glochidioides, Phyllanthus aff. glochidioides.

\section{Phyllanthus securinegoides type - Fig. 10}

Pollen grains prolate spheroidal. $\mathrm{P}=22.9-24.3 \mu \mathrm{m}, \mathrm{E}=21.9$ $22.9 \mu \mathrm{m}, \mathrm{P} / \mathrm{E}=1.00-1.11$.

Aperture system - 4-colporate, colpi with smooth margins.

Ornamentation - Reticulate.

Species included $-P$. securinegoides.

\section{Pilate type - Fig. 11}

Pollen grains subprolate. $\mathrm{P}=14.3 \mu \mathrm{m}, \mathrm{E}=11.0-12.3 \mu \mathrm{m}, \mathrm{P} / \mathrm{E}$ $=1.16-1.30$.

Aperture system - 4-colporate, colpi obscure using SEM. Ornamentation - Pilate, pila mostly with rounded capita.

Note - This type is similar to the inaperturate pollen grains of $P$. attenuatus (subg. Conami, sect. Hylaeanthus; Webster \& Carpenter 2002), but differs by the presence of colpi.

Species included - Phyllanthus sp. A.
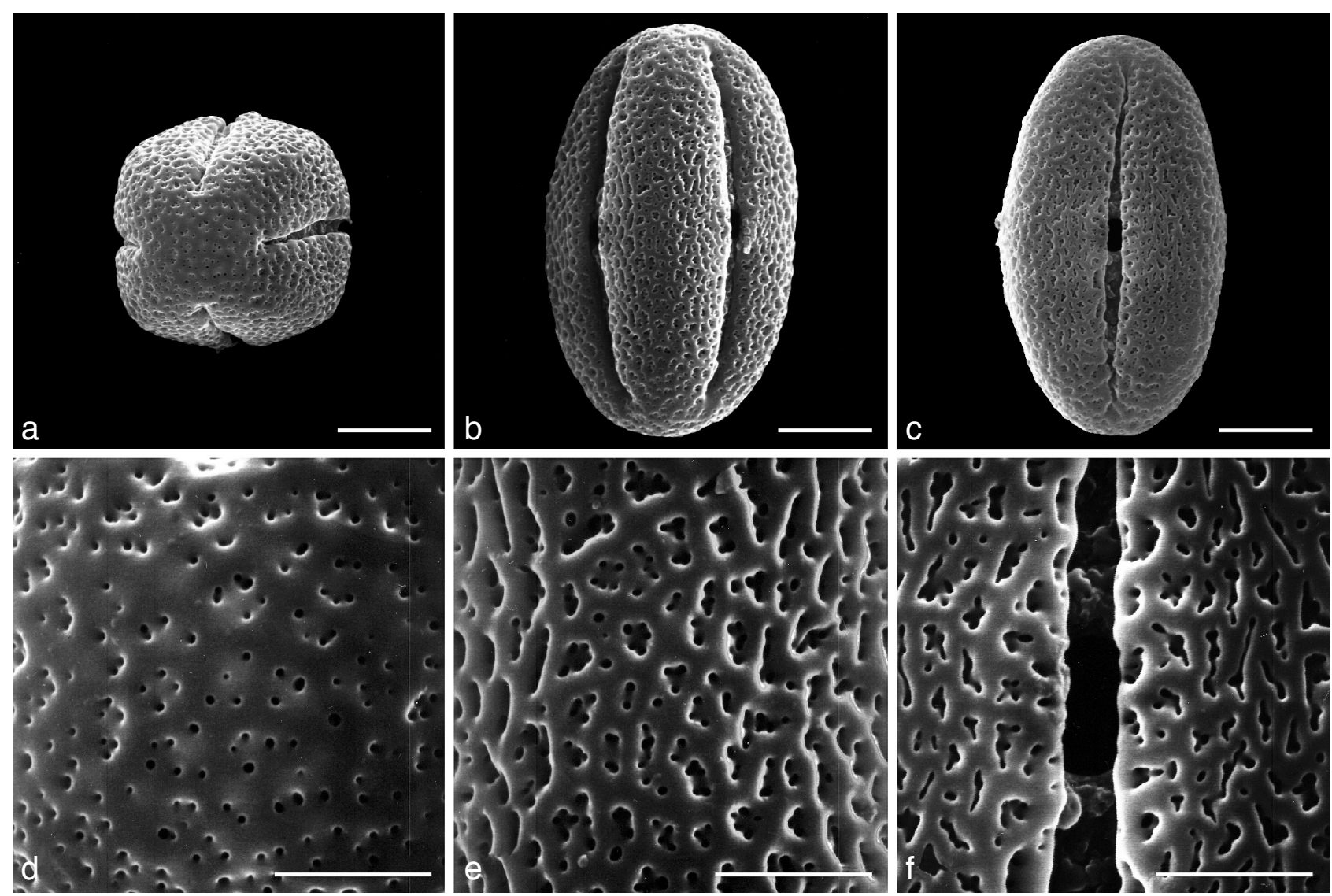

Fig. 6 Scanning electron micrographs of the Phyllanthus urinaria type. $a-f$. $P$. benguetensis. - Scale bars: $a-c=5 \mu m, d-f=2 \mu m$. 

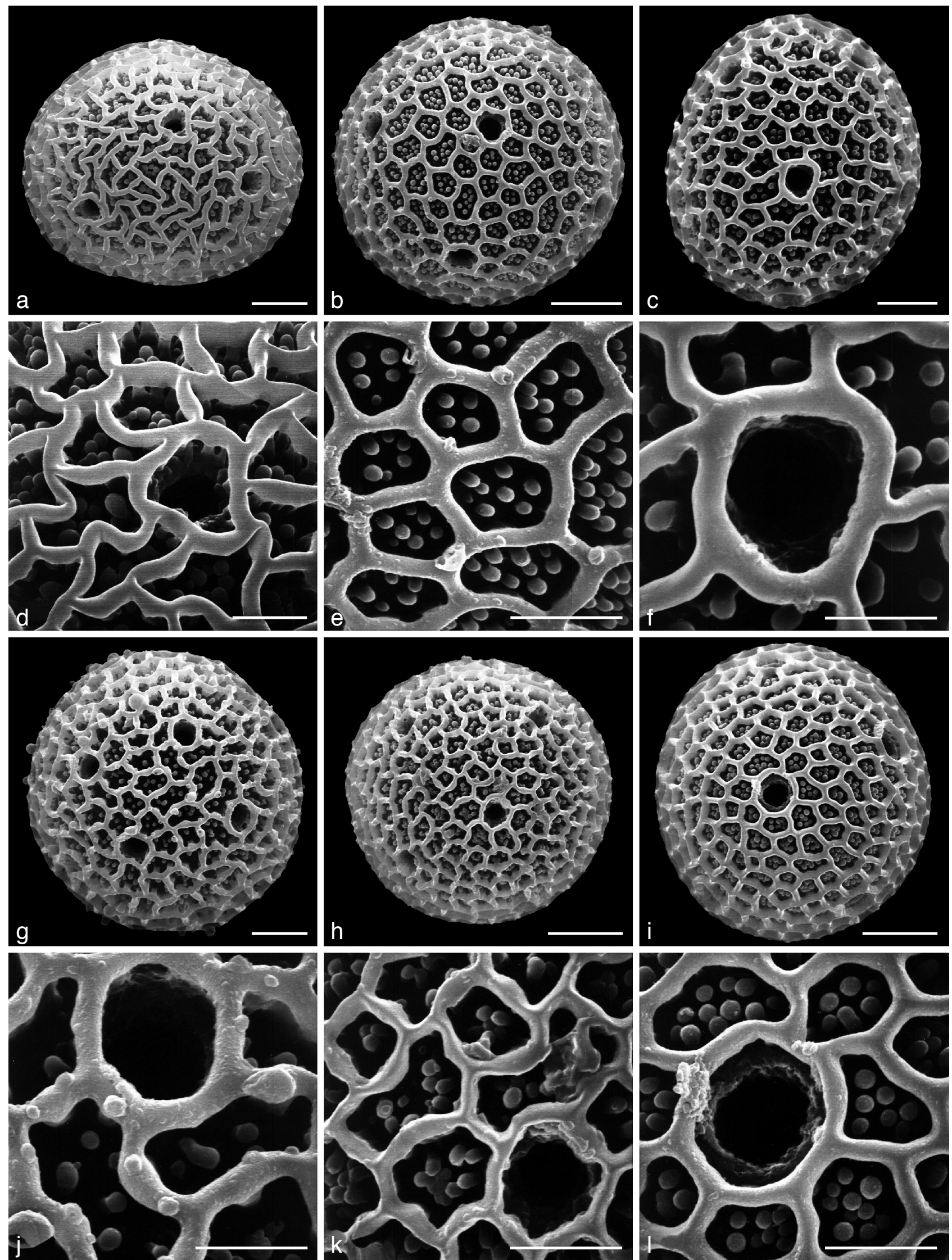

Fig. 7 Scanning electron micrographs of the Phyllanthus buxifolius type. a, d. P. buxifolius; b, e. P. kinabaluicous; c, f. P. lamprophyllus; g, j. P. megalanthus; h, k. P. mindorensis; i, I. P. sibuyanensis. — Scale bars: $\mathrm{a}-\mathrm{c}, \mathrm{g}-\mathrm{i}=5 \mu \mathrm{m} ; \mathrm{d}-\mathrm{f}, \mathrm{j}-\mathrm{I}=2 \mu \mathrm{m}$. 

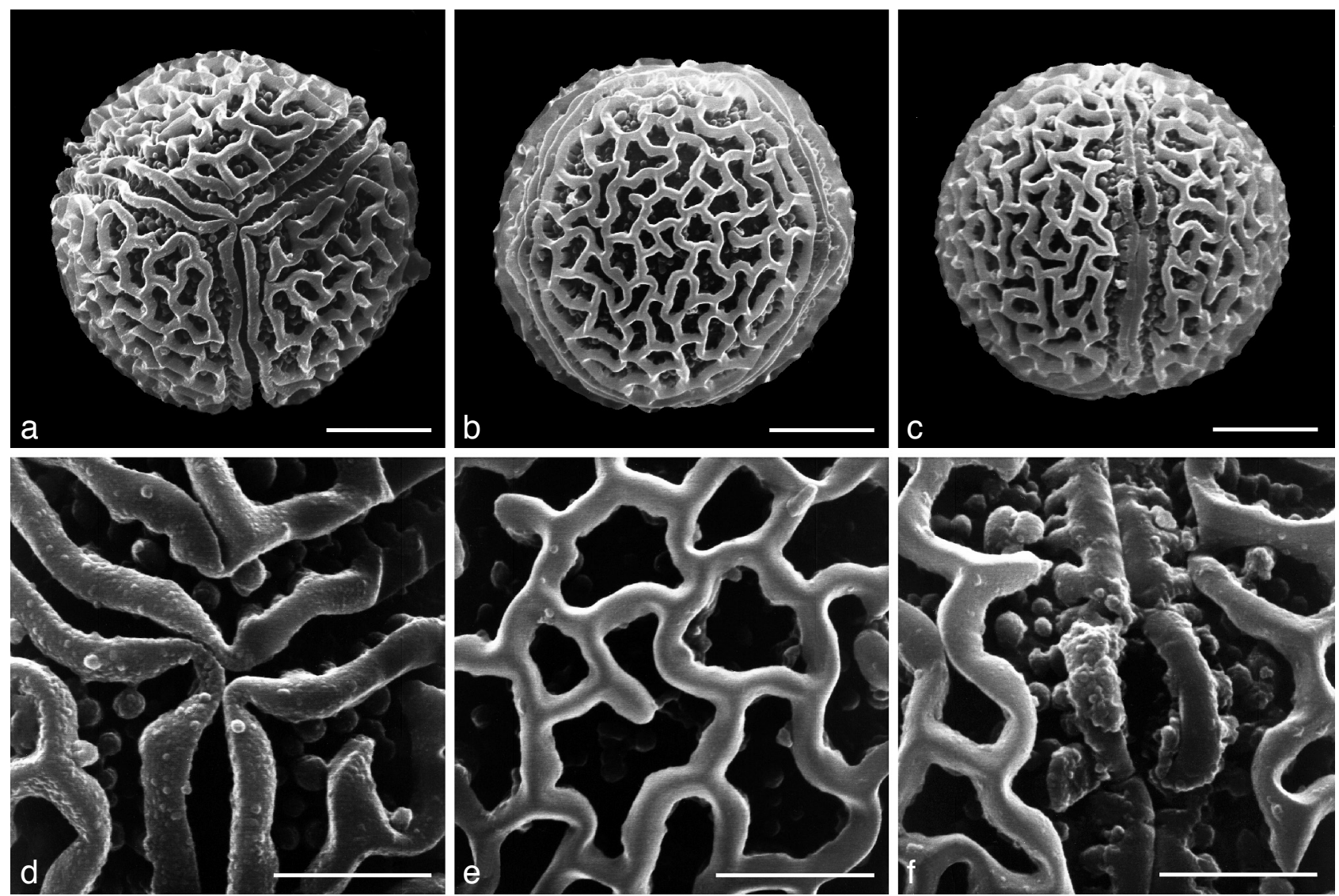

Fig. 8 Scanning electron micrographs of the Phyllanthus maritimus type. $a-f$. $P$. ramosii. - Scale bars: $a-c=5 \mu m, d-f=2 \mu m$.

\section{DISCUSSION}

\section{Pollen types and infrageneric classification}

Five of the 11 pollen types in Philippine Phyllanthus each occur in a single section (Table 2). The $P$. amarus type and $P$. urinaria type, both belonging to subg. Phyllanthus, have the same bireticulate ornamentation, but differ in the number of colpi. The $P$. acidus type, $P$. casticum type and $P$. maritimus type share reticulate exine ornamentation. However, the $P$. maritimus type has granules in the lumina. The $P$. acidus type and $P$. casticum type (both subg. Kirganelia) can be distinguished by the length of their colpi.

Two pollen types occur in more than one section: the $P$. virgatus type in the two sections of subg. Isocladus, the P. buxifolius type in the three sections of subg. Eriococcus. The P. buxifolius type, found in six species, is homogeneous. The $P$. virgatus type, found in four species, varies in the morphology of the colpus margins. Phyllanthus aff. samarensis has colpus margins consisting of a single murus, while the other species have colpus margins comprising two muri. Therefore, it might be appropriate to describe a different subtype for $P$. aff. samarensis. Evidently, the areolate pollen of $P$. lanceifolius (sect. Paraphyllanthus; Merrill 1914) is closer to that of sect. Macraea than to the 3colporate pollen of $P$. erythrotrichus (sect. Paraphyllanthus; Punt 1967, 1987). Transferring $P$. lanceifolius to sect. Macraea should therefore be considered.

Pollen morphologically, subg. Gomphidium, including three pollen types, is most heterogeneous in Philippine Phyllanthus. The P. maritimus type (sect. Adenoglochidion) is 3-syncolporate. The $P$. glochidioides type and $P$. securinegoides type (both sect. Gomphidium) have 4-colporate pollen. They differ by their exine ornamentation and the morphology of the colpus margins.
Merrill (1914) found $P$. securinegoides hard to classify. He noticed that $P$. securinegoides did not fit in sect. Gomphidium, because the scarce styles are united, spreading and prominently cleft. Hence, he suggested that a new section should be described. Pollen morphology confirms Merrill's opinion.

Phyllanthus sp. A has not been assigned to a section and subgenus yet. Its pollen (Pilate type), is similar to the pilate pollen of $P$. attennutus (subg. Conami, sect. Hylaeanthus; Webster \& Carpenter 2002), but has a 4-colporate apertural system.

\section{Pollen types and phylogenetic relationships}

Subgenera Isocladus, Kirganelia and Phyllanthus are not monophyletic, based on ITS and matK DNA sequence analyses (Kathriarachchi et al. 2006). According to these data, sect. Paraphyllanthus is more primitive than sect. Macraea (subg. Isocladus), sect. Anisonema more primitive than sect. Cicca (subg. Kirganelia) and $P$. amarus more primitive than sect. Urinaria (subg. Phyllanthus). Punt (1967) considered an increased number of colpi as a derived feature. Thus, the $P$. erythrotrichus type of sect. Paraphyllanthus would be more primitive than the $P$. virgatus type of sect. Macraea, and the P. amarus type of sect. Phyllanthus is more primitive than the $P$. urinaria type of sect. Urinaria. In these cases the pollen morphological trend proposed by Punt is concordant with the DNA sequence data. According to Punt (1967), the colporate $P$. acidus type of sect. Cicca is more primitive than the syncolporate $P$. casticum type of sect. Anisonema. This conflicts with the DNA sequence data. However, comparing the ornamentation in detail, the $P$. casticum type of sect. Anisonema has a primitive reticulate ornamentation and the $P$. acidus type of sect. Cicca has an advanced rugulate-reticulate ornamentation. This result tells us that the ornamentation trend is concordant with the DNA sequence data of Kathriarachchi et al. (2006). 


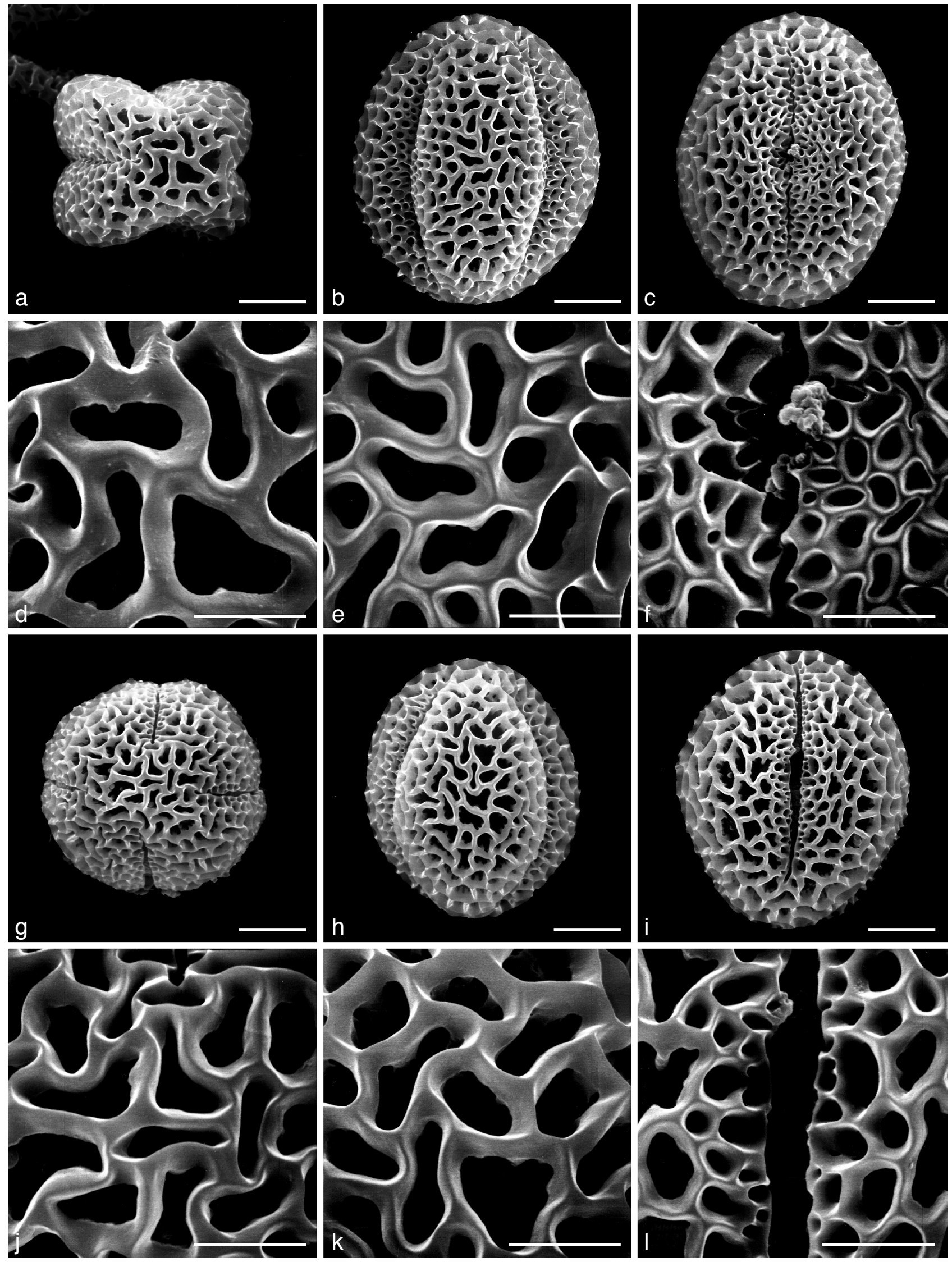

Fig. 9 Scanning electron micrographs of the Phyllanthus glochidioides type. a-f. P. glochidioides; g-l. Phyllanthus aff. glochidioides. — Scale bars: a-c, $g-i=5 \mu \mathrm{m} ; d-f, j-I=2 \mu \mathrm{m}$. 

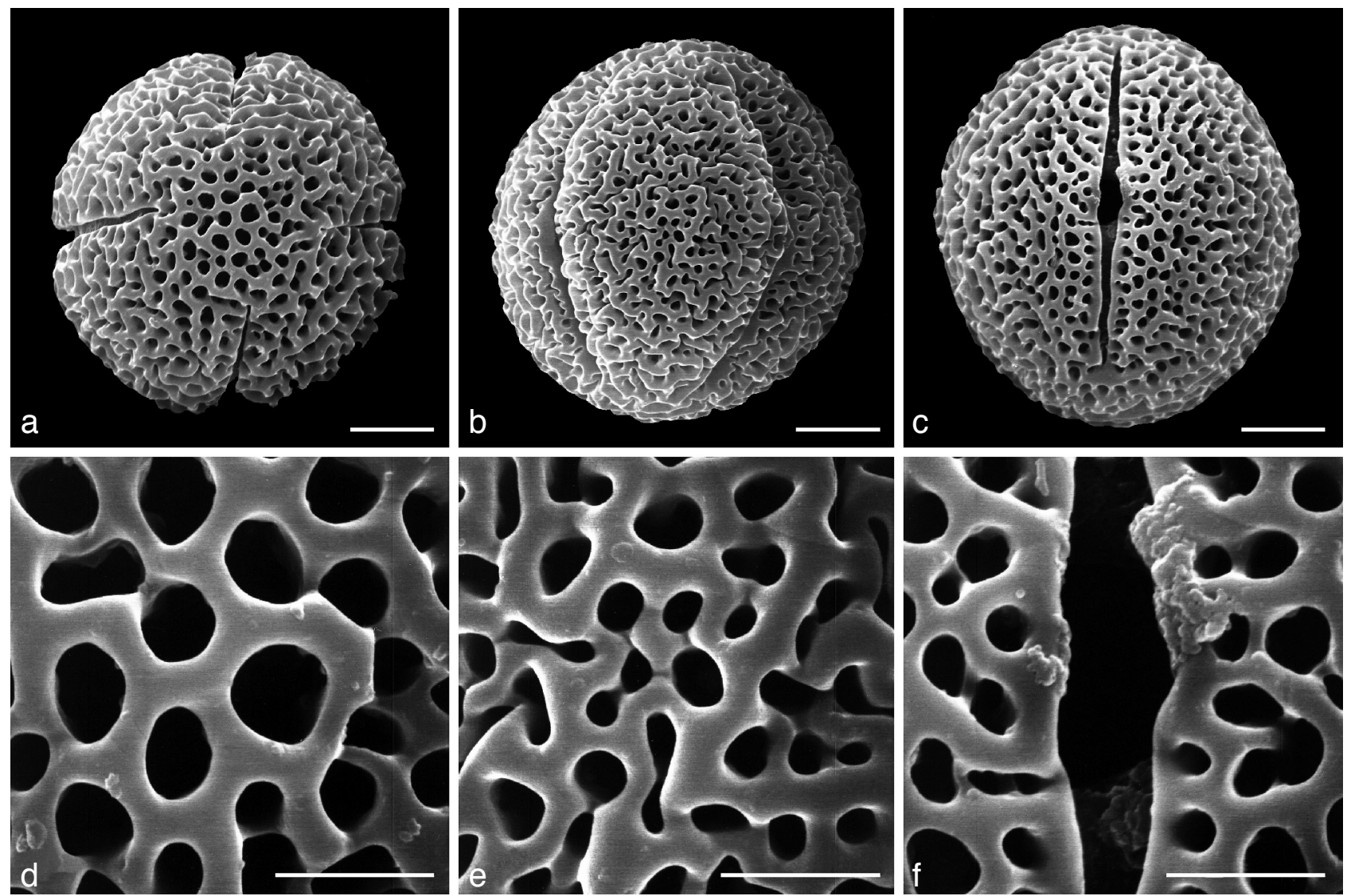

Fig. 10 Scanning electron micrographs of the Phyllanthus securinegoides type. a-f. P. securinegoides. - Scale bars: $a-c=5 \mu \mathrm{m}, d-f=2 \mu \mathrm{m}$.
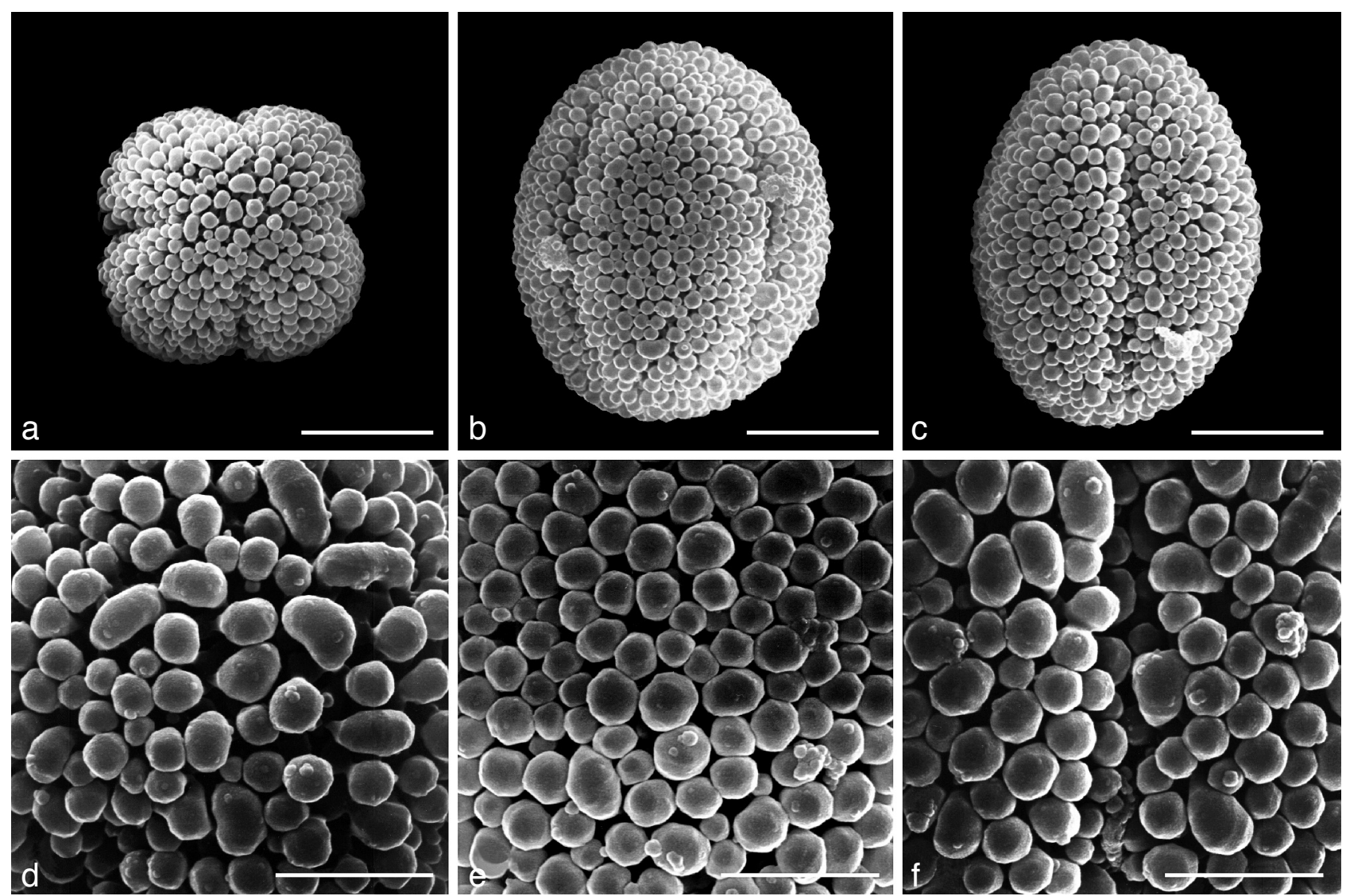

Fig. 11 Scanning electron micrographs of the Pilate type. a-f. Phyllanthus sp. A. - Scale bars: $a-c=5 \mu \mathrm{m}, d-f=2 \mu \mathrm{m}$. 
Acknowledgements We would like to express our sincere thanks to the directors of the National Herbarium Nederland $(L)$ and the Jose Vera Santos Memorial Herbarium (PUH) for the loan of specimens and providing pollen materials. We appreciate the anonymous reviewer for providing advice and editing our English, and Dr Peter van Welzen and Mr Leonardo Co for providing references. Thanks also to Ms Jin-Yen Lin and Ms Ya-Yun Yang, National Taiwan University, for their assistance in using the scanning electron microscope. This study was supported in part by the National Science Council (grant no. NSC95-2621-B-026-001), Executive Yuan, Taiwan.

\section{REFERENCES}

Airy Shaw HK. 1983. An alphabetical enumeration of the Euphorbiaceae of the Philippine Islands. Royal Botanical Gardens, Kew.

Bor J. 1979. Pollen morphology and the bi-reticulate exine of the Phyllanthus species (Euphorbiaceae) from Mauritius and Reunion. Review of Paleobotany and Palynology 27: 149-172.

Chen S-H, Wu M-J. 1997. A revision of the herbaceous Phyllantus L. (Euphorbiaceae) in Taiwan. Taiwania 42: 239-261.

Elmer ADE. 1908. A century of new plants. Leaflets of Philippine Botany 1: $272-359$.

Elmer ADE. 1910. Euphorbiaceae collected on Sibuyan Island. Leaflets of Philippine Botany 3: 901-931.

Elmer ADE. 1911. Euphorbiaceae collected on Palawan Island. Leaflets of Philippine Botany 4: 1271-1306.

Erdtman G. 1952. Pollen morphology and plant taxonomy: angiosperms. Almquist \& Wiksell, Stockholm.

Govaert R, Frodin DG, Radcliffe-Smith A. 2000. World checklist and bibliography of Euphorbiaceae, vol. 4. Royal Botanic Gardens, Kew.

Hoffmann P, Barker AJM, Madulid DA, Proctor J. 2003. Phyllanthus balgooyi (Euphorbiaceae s.I.), a new nickel-hyperaccumulating species from Palawan and Sabah. Blumea 48: 193-199.

Huang T-C. 1972. Pollen flora of Taiwan. 1st ed. Botany Department, National Taiwan University, Taipei 106, Taiwan.

Kathriarachchi H, Samuel R, Hoffmann P, Mlinarec J, Wurdack KJ, Ralimanana H, Stuessy TF, Chase MW. 2006. Phylogenetics of tribe Phyllantheae (Phyllanthaceae; Euphorbiaceae sensu lato) based on nrlTS and plastid matK DNA sequence data. American Journal of Botany 93: 637-655.

Köhler E. 1965. Die Pollenmorphologie der biovulaten Euphorbiaceae und ihre Bedeutung für die Taxonomie. Grana Palynologica 6: 26-120.

Köhler E. 1967. Über Beziehungen zwischen Pollenmorphologie und Polyploidiestufen im Verwandtschaftsbereich der Gattung Phyllanthus (Euphorbiaceae). Feddes Repertorium 74: 159-165.

Lobreau-Callen D, Punt W, Schmid M. 1988. Pollen morphology and taxonomy of the Phyllanthus species (Euphorbiaceae) native to New Caledonia. Review of Paleobotany and Palynology 53: 283-304.

Long $\mathrm{H}, \mathrm{Yu} \mathrm{C}-\mathrm{H}$. 1984. Intrageneric variation of pollen types in the genus Phyllanthus L. Acta Botanica Sinica 26: 247-251.

Meewis B, Punt W. 1983. Pollen morphology and taxonomy of the subgenus Kirganelia (Jussieu) Webster (genus Phyllanthus, Euphorbiaceae) from
Africa. Review of Paleobotany and Palynology 39: 131-160.

Merrill ED. 1912. Notes on Philippine Euphorbiaceae. Philippine Journal of Science. Section C, Botany 7: 379-410.

Merrill ED. 1914. Notes on Philippine Euphorbiaceae, II. Philippine Journal of Science. Section C, Botany 9: 461-493.

Merrill ED. 1920. Notes on Philippine Euphorbiaceae, III. Philippine Journal of Science 16: 539-579.

Merrill ED. 1923. An enumeration of Philippine flowering plants 2: 391-396. Bureau of Printing, Manila.

Punt W. 1967. Pollen morphology of the genus Phyllanthus (Euphorbiaceae). Review of Paleobotany and Palynology 3: 141-150.

Punt W. 1972. Pollen morphology and taxonomy of section Ceramanthus Baillon s.l. of the genus Phyllanthus (Euphorbiaceae). Review of Paleobotany and Palynology 13: 213-228.

Punt W. 1980. Pollen morphology of the Phyllanthus species (Euphorbiaceae) occurring in New Guinea. Review of Paleobotany and Palynology 31: 155-177.

Punt W. 1987. A survey of pollen morphology in Euphorbiaceae with special reference to Phyllanthus. Botanical Journal of the Linnean Society 94 $127-142$.

Punt W, Hoen PP, Blackmore S, Nilsson S, Le Thomas A. 2007. Glossary of pollen and spore terminology. Review of Paleobotany and Palynology 143: 1-81.

Punt W, Rentrop J. 1973. Pollen morphology of the Phyllanthus species (Euphorbiaceae) occurring in the continental United States. Review of Paleobotany and Palynology 16: 243-261.

Quisumbing E, Merrill ED. 1928. New Philippine plants. Philippine Journal of Science 37: 133-212.

Robinson CB. 1909. Philippine Phyllanthinae. Philippine Journal of Science. Section C, Botany 4: 71-106.

Robinson CB. 1911. Alabastra Philippinensia, III. Philippine Journal of Science. Section C, Botany 6: 319-358.

Rossignol L, Rossignol M, Haicour R. 1987. A systematic revision of Phyllanthus subsection Urinaria (Euphorbiaceae). American Journal of Botany 74: 1853-1862.

Sagun VG, Van der Ham RWJM. 2003. Pollen morphology of the Flueggeinae (Euphorbiaceae, Phyllanthoideae). Grana 42: 193-219.

Santiago LJM, Louro RP, Emmerich M, Barth OM. 2004. The pollen morphology of Phyllanthus (Euphorbiaceae) section Choretropsis. Botanical Journal of the Linnean Society 144: 243-250.

Schmid M. 1991. Phyllanthus. In: Morat P, Mackee HS (eds), Flore de la Nouvelle-Calédonie et Dépendances 17: 31-320. Muséum National d'Histoire Naturelle, Paris, France.

Webster GL. 1956. A monographic study of the West Indian species of Phyllanthus. Journal of the Arnold Arboretum 37: 217-268.

Webster GL. 1986. A revision of Phyllanthus (Euphorbiaceae) in Eastern Melanesia. Pacific Science 40: 88-105.

Webster GL, Carpenter K. 2002. Pollen morphology and phylogenetic relationships in neotropical Phyllanthus (Euphorbiaceae). Botanical Journal of the Linnean Society 138: 325-338.

Wei W-Z, Kiu H-S, Zhou L-H. 2002. Pollen morphology of Phyllanthus (Euphorbiaceae). Acta Botanica Yunnanica 24: 253-259. 